\title{
Från Pennskaft till Väckarklocka. Elin Wägners bildningsväg
}

\author{
Av Solveig Hammarbäck, universitetsadjunkt i svenska
}

\author{
Länk till presentation av Solveig Hammarbäck
}

\begin{abstract}
Vårterminen 1898 har den 16-åriga Elin Wägner gått ut flickskolan i Helsingborg efter en barndom och skolgång som präglats av personliga förluster och genomgripande förändringar. Då går hon in till sin far, rektorn för gossläroverket, Sven Wägner, och ber honom om extra lektioner för att kunna förbereda sig för en studentexamen som privatist. Fadern/ rektorn säger nej utan att, vad vi vet i alla fall, förebära något skäl. Elin Wägner tolkade hans besked som att det berodde på hennes kön. Senare får hon också mycket riktigt se sin tre år yngre bror, Harald Wägner, helt naturligt fortsätta sina studier vid gymnasium och universitet (Isaksson \& Linder, 1977).
\end{abstract}

För mig är det en egendomlig upplevelse att 100 år senare, våren 1998, sitta i Elins hus Lilla Björka och höra Harald Wägners dotter, Ria Wägner, säga: "Tänk, jag kunde aldrig förstå varför Faster alltid med bitterhet drog fram sina bristande studier och den orättvisa som vederfarits henne som inte fått studera. Jag som tyckte att skolan var bortkastad tid".

Nej, det blev inga högre studier för Elin Wägner och inte heller för tusentals andra unga kvinnor i hennes generation. Idag vet vi att hon ändå skulle bli en författare som fortfarande läses och numera hyllas för sin stora framsynthet på flera områden som vår tid räknar som de allra angelägnaste. Av sin egen tids smakdomare ansågs hon t.o.m. värd att få bli den andra kvinnan efter Selma Lagerlöf att ta plats i Svenska Akademien. Man kan med skäl fråga sig hur hon lyckades ta sig fram till den positionen, ja, hur hennes bildningsväg såg ut.

Framtiden såg verkligen inte särskilt lysande ut för Elin Wägner året 1898. Efter en kortare kurs på en handelsskola fick hon börja som skrivbiträde på pappas rektorsexpedition, och där kanske hon hade kunnat bli kvar om hon inte haft ett stort intresse som hon utövade på fritiden: hon skrev, noveller och kåserier. Redan 1899 fick hon pris för en novell i ungdomstidningen Linnea och så småningom får hon recensioner och kåserier publicerade i Helsingborgs-Posten som erbjuder henne en fast anställning 1903.

Det är lätt att se en parallell mellan Elin Wägners inträde i vuxenlivet och Astrid Lindgrens, även om den senare är 25 år yngre och kommen ur en annan och inte alls intellektuell miljö. Båda försöker de med sitt skrivande att pröva vingarna och kanske spränga de trånga ramar som hörde till unga flickors villkor vid denna tid. Genom trassliga erfarenheter och sviken kärlek hamnar båda också så småningom i Stockholm, och när Elin Wägner skriver sin första roman, Norrtullsligan 1908, så föregriper hon det Stockholmsliv som Astrid Lindgren får uppleva när hon i slutet av 20-talet kommer att tillhöra ett kontoristproletariat av unga kvinnor som försöker försörja sig på en omöjligt liten lön (Strömstedt, 1987). I Norrtullsligan beskrivs flickornas liv med galghumor och ironi, men Astrid Lindgren har berättat om hur verkligheten såg ut när penningbristen tvingade fyra flickor att slå sig ihop och hyra ett rum med två sängar, där man sov i skift.

Men Elin Wägner själv kom inte till Stockholm som kontorist utan som journalist på tidningen Idun, och det är också journalistmiljön hon använder sig av i sin nästa roman, Pennskaftet, 1910. Den blir en verklig succé, inte minst för att den har djärvheten att för första gången visa upp en självständig yrkeskvinna som brinner för sitt arbete och 
samtidigt vill leva tillsammans med mannen som hon älskar - en omöjlig kombination enligt den tidens sätt att se. Till detta kommer inblickarna i något helt nytt i samhällslivet: kampen för den kvinnliga rösträtten. Romanen låter huvudpersonen Pennskaftet följa kampen som journalist, men hon dras också in i den så att läsarna får följa hennes framväxande övertygelse och kamplust.

Och därmed är vi inne på Elins eget liv. Arbetet som journalist har givit henne kontakter med tidens rösträttskvinnor och snart är hon själv engagerad i kampen för att skaffa kvinnorna rösträtt. En bild av henne från 1914 visar hur hon stolt redovisar resultatet från en namninsamling för kvinnlig rösträtt som fått en imponerande anslutning. Hon är nu en ung kvinna på 32 år, gift med filosofen John Landquist, och med ett intressant yrkesliv som ger henne mer kunskaper och erfarenheter än varken hon själv eller pappa rektorn kunnat ana (Isaksson \& Linder, 1977).

Arbetet som journalist låter henne också möta andra idéer och kunskaper. 1914 har första världskriget utbrutit och Elin Wägner får kontakt med en grupp kvinnor ur rösträttsrörelsen med många internationella kontakter. Ute i Europa har man insett att freden kanske är den viktigaste förutsättningen för förverkligandet av kvinnors rösträtt. 1915 deltar Elin Wägner i sin första internationella fredskonferens i Haag, och så snart kriget är slut börjar en period i hennes liv då hon ofta befinner sig på resa. Hennes äktenskap är upplöst och hon känner sig fri att som reporter uppsöka många farliga och politiskt problematiska miljöer, t.ex. Rhenlandet, som efter krigsslutet fått nya gränser som människorna har svårt att acceptera. En ström av artiklar och böcker visar på Elin Wägners växande engagemang för frågan om hur människor ska kunna leva i en fredlig samvaro. Läsningen av Gandhis skrifter betyder naturligtvis mycket för henne i denna fråga, men det är också typiskt för henne att hon själv vill ta reda på förhållandena på plats, själv försöka sätta sig in i människors situation, innan hon tar ställning eller kommer med förslag till lösningar.

Under rösträttsarbetet har Elin Wägner förstått att det finns oändligt många kvinnor som liksom hon själv inte fått tillräcklig utbildning och därför inte heller kan utnyttja den erövrade rösträtten till att vara med och ta ansvar för politik och samhällsarbete. Ett fruktbart nätverk uppstår när hon tillsammans med Elisabeth Tamm, Ada Nilsson, Honorine Hermelin och Kerstin Hesselgren lyckas förverkliga idén om en kvinnlig medborgarskola på Elisabeth Tamms släktgods Fogelstad. Genom detta samarbete formas och påverkas stora skaror av kvinnor som får tillfälle att delta i skolans kurser från 20-talet ända fram till skolans nedläggning 1954.

"Jag kom till Fogelstad som ett ingenting och cyklade därifrån som en människa", säger en av kursdeltagarna i den musikteater som de två senaste somrarna har försökt att ge ett smakprov på den utbildning för livet som gavs där till kunskapshungrande kvinnor från alla samhällsklasser. Visst, kvinnor fick lära sig att cykla där, och det höjde självförtroendet och gav möjligheter till en större aktionsradie. Men det viktigaste var ändå den "learning-bydoing-pedagogik" som konsekvent tillämpades där, med samhällskunskap och föreningsteknik i lekfull rollspelsform representerat av låtsassamhället Komtemåtta. Elin Wägner och många andra var återkommande föreläsare som delade med sig både av bokliga kunskaper och egna erfarenheter.

Skildringarna från Fogelstadkurserna blir ofta starkt positiva, och framför allt i kursdeltagarnas minnesbilder framstår tiden där som en enda lång kamrat- och kunskapsfest. Men för de fem ledarna på skolan var kurserna bara en del av deras påverkansarbete. Samtidigt engagerade de sig i utgivningen av tidskriften Tidevarvet som ville vara en kvinnligt inriktad politisk veckotidning för demokrati, pacifism och rättssamhälle. Under Tidevarvets utgivningstid 1923-36 arbetade Elin Wägner där, först som redaktör och efter 1927 som fristående medarbetare. Tidskriften hade ständigt ekonomiska bekymmer och problemen slet hårt på gruppens vänskap och sammanhållning. 1935 samlades man dock för att mobilisera kvinnorna för en gemensam kamp mot upprustningen i Europa, Kvinnornas vapenlösa uppror eller Första september-rörelsen. Den hade till syfte att få kvinnor över hela Europa att vägra använda alla typer av skyddsvapen, 
gasmasker och skyddsrum i förhoppningen att inga män skulle vilja angripa helt försvarslösa kvinnor och barn (Andersson, 1999). Elin Wägner engagerade sig starkt i Första september-rörelsen och använde hela sitt journalistiska kunnande för att få kvinnorna att ansluta sig, och aktionen samlade verkligen oväntat många. Men när Hitlers arméer obevekligt började röra på sig insåg de flesta att det vapenlösa upproret var orealistiskt, och Elin Wägner tvingades besviket konstatera att hon misstagit sig på kvinnornas demokratiska möjligheter att skapa sig ett fredligt samhälle.

1937 är det dags för en ny stor internationell fredskonferens, den här gången i Bratislava. Här möter Elin Wägner oväntat nya idéer som fångar hennes intresse. En enkel schweizisk bondkvinna, Mina Hofstätter, berättar där om sina positiva erfarenheter av att söka sig tillbaka till ett äldre, mer naturenligt sätt att bruka jorden. Djur och människor på hennes gård har fått tillbaka hälsan efter det att man konsekvent börjat använda kompost och gröngödsling i stället för de nu alltmera utbredda syntetiska gödningsmetoderna, som visserligen gav ökade skördar men som samtidigt bidrog till att suga ut jordens resurser. Elins vän Flory Gate är med i Bratislava och vid hemkomsten startar ett intensivt litteraturstudium för att få veta mera. Svåråtkomliga böcker spåras upp och lånas via vänner och tillsammans försöker de båda att översätta de verk som de finner viktigast om gamla sätt att odla och om andra kulturers sätt att leva på jorden (Isaksson \& Linder, 1982). Men teorier räcker inte. Man måste pröva deras hållbarhet i praktiskt utförande, och Elin följer därför intresserat Florys ekologiska odlingsförsök på den gård som hon nu skaffar sig i närheten av Elins Lilla Björka.

1941 är Elin Wägner klar med sin nya vision för ett bättre samhälle som hon presenterar i Väckarklocka. Fred på jorden går inte att uppnå utan fred med jorden. Utsugningen av jorden, överexploateringen av naturresurserna leder ofelbart till motsättningar mellan folkgrupper och så småningom till stridigheter. Fred med jorden uppnås lättast , menar Elin Wägner, om kvinnorna får vara med och bestämma över fördelningen i samhället. I alla tider har mödrar vetat att man inte får överutnyttja naturens resurser: man måste spara lite till återväxten, till nästa års utsäde, annars har man inget att ge sina hungriga barn då.

Elin Wägner hade stora förhoppningar på Väckarklocka men hon tvingades besviket konstatera att den inte särskilt uppskattades av sin samtid. Därtill bidrog förstås att den kom ut mitt under brinnande världskrig men också att den till form och innehåll ibland kan förefalla ostrukturerad och svårtillgänglig. Det är först i våra dagar som man verkligen förstått Elin Wägners storhet när det gäller att klarlägga de ekologiska frågorna som vi brottas med idag. När Rachel Carsons bok Tyst vår väcker stort uppseende 1962 har de flesta glömt Elin Wägners pionjärarbete. Bara Vilhelm Moberg påminner om Elins verk och konstaterar bittert: "De som har rätt för tidigt blir glömda och förgätna. Deras eftersägare blir hyllade och berömda" (Domeij, 1998:66).

Besvikelsen över Väckarklockas mottagande hindrade inte Elin Wägner att gå vidare och snart kan hon glädja sig åt att hennes biografi över Selma Lagerlöf 1942-43 blir så uppskattad att hon 1944 själv väljs in som en av de Aderton. Därmed får hon en officiell bekräftelse på att det 30-tal romaner och novellsamlingar som hon utgivit - och som till stor del finansierat det livslånga journalistiska och politiska arbetet med att föra ut de många gånger obekväma idéerna om kvinnors rättigheter och nödvändigheten av fred och varsamhet med jordens resurser - kommer att räknas in bland de verk i den svenska 1900talslitteraturen som den tidens smakdomare ansåg värda att minnas av eftervärlden. Och det är förstås ingen dålig avslutning på en bildningsväg för en ung flicka som förvägrades den skolgång som var naturlig för hennes bror.

En fråga som man ställer sig idag 50 år efter hennes död, när Elin Wägners idéer visat sig vara mer långlivade än hennes romaner, är: vad var det för kunskaper och färdigheter som möjliggjorde denna hennes bildningsväg från Pennskaft till Väckarklocka? Ett uttömmande svar på den frågan kräver mer djupgående studier inte bara i Elin Wägners liv och verk utan också i den tid hon levde i. Jag nöjer mig med att peka på tre viktiga faktorer i hennes utrustning och omgivning. 
Först och främst tror jag att hennes lust och förmåga i skrivandet är betydelsefulla som en viktig inkörsport till nya sammanhang, för att pröva nya kunskaper och idéer. Skrivandet hjälper henne också i uppbyggandet av de internationella kontakter som är en andra förutsättning för hennes utveckling. Gång på gång har resor och kontakter med nya idéer visat sig vara avgörande för hennes tänkande. Här måste man också lyfta fram och beundra de gedigna språkkunskaper som hon hunnit skaffa sig under sin korta skoltid.

En tredje och kanske avgörande egenskap hos Elin Wägner är hennes öppenhet inför nya idéer och hennes förmåga att se samband, sammanhang och möjligheter som inte är omedelbart urskiljbara. Hunnen så här långt så inser jag att Elin Wägners bildningsgång präglas av precis det som vi idag lyfter fram som fundamentalt i den utbildning som vi vill ge här på Växjö universitet; vi använder bara de lite modernare orden skrivkultur, internationalisering och tvärvetenskap, när vi presenterar vår verksamhet för omvärlden.

Därför tycker vi i Elin Wägner-sällskapet att det är helt på sin plats att Växjö universitet påminner dagens studenter om Elin Wägners person och verk genom att döpa en av undervisningssalarna till Wägner-salen. Vi har också utlyst ett Elin Wägner-stipendium till den student som skriver den bästa C- eller D-uppsatsen om Elin Wägner och hennes verk eller i hennes anda: om jämställdhet, om fred och konfliktlösning, om hushållning och miljötänkande - eller kanske om en pedagogik för att lära ut de kunskaper som vi idag inser vara absolut nödvändiga för att vi ska ha möjligheter att leva vidare in i nästa årtusende.

\section{Referenser:}

Andersson, Irene, Tidevarvet - plattform för ett vapenlöst uppror. I Presshistorisk årsbok 1999. Stockholm 1999.

Domeij, Åsa, Hur jag började läsa Vilhelm Moberg. I von Friesen, Otto (red.), Vilhelm Moberg, sanningen och friheten. Växjö 1998.

Isaksson, Ulla \& Linder, Erik Hjalmar, Elin Wägner. Amason med två bröst. Bonniers 1977.

Isaksson, Ulla \& Linder, Erik Hjalmar, Elin Wägner. Dotter av Moder Jord. Bonniers 1980.

Strömstedt, Margareta, Astrid Lindgren. Stockholm, 1987.

(C) Solveig Hammarbäck 